\title{
FREE RADICAL SCAVENGING AND ANTIMICROBIAL PROPERTIES OF EXTRACTS OF WILD MUSHROOMS
}

\author{
Oyetayo, V.O. \\ Department of Microbiology, Federal University of Technology, P.M.B 704, Akure, Nigeria
}

Submitted: May 09, 2008; Returned to authors for corrections: August 16, 2008; Approved: March 31, 2009.

\begin{abstract}
Antioxidant and antimicrobial potentials of extracts obtained from four wild mushrooms, Termitomyces clypeatus (TCE), Termitomyces robustus (TRE), Lentinus subnudus (LSE) and Lenzites species (LZE) collected in Nigeria were investigated. LSE and LZE displayed good scavenging activity against 2, 2-Diphenyl-1Picrylhydrazyl (DPPH) and ferrous ion radicals at concentration of $2 \mathrm{mg} / \mathrm{mL}$. However, TRE and TCE exhibited better superoxide anion scavenging effect at $2 \mathrm{mg} / \mathrm{mL}$. All extracts (TCE, TRE, LSE and LZE) had comparable scavenging effect on hydroxyl radicals as butylated Hydroxytoluene (BHT) used as control. Moreover, extracts from the wild mushrooms were able to inhibit the growth of all indicator organisms at concentrations between $12.5 \mathrm{mg} / \mathrm{mL}$ to $100 \mathrm{mg} / \mathrm{mL}$. LSE and LZE, however, showed better antimicrobial effect on the indicator organisms. The results suggest that extracts obtained from the four wild mushrooms may serve as sources of new bioactive compounds with effective antioxidant and antimicrobial activity.
\end{abstract}

Key words: wild mushrooms, antimicrobial activity, free radical scavenging

\section{INTRODUCTION}

In the last three decades, the search for natural bioactive compounds that can serve as antioxidant and antimicrobial agents had increased tremendously. The reasons for these are increasing understanding of the harmful nature of reactive oxygen species (ROS) produced during oxidation processes, harmful nature of synthetic antioxidant such as butylated hydroxyanisole (BHA) and butylated hydroxytoluene (BHT) and the increasing resistance posed by microorganisms to synthetic antibiotics. Extracts from mushroom have received attention based on their safety and records of health promotion.

Mushrooms produce a wide range of secondary metabolites with high therapeutic value (9). Health promoting properties such as antioxidant, antimicrobial, anticancer, cholesterol lowering and immunostimulatory effects, have been reported for some species of mushrooms $(5,19,20)$. Both fruiting body and the mycelium contain compounds with wide-ranging antioxidant and antimicrobial activities $(5,11)$.
The antioxidative and free radical scavenging properties of the phenolic content of mushroom methanol extracts have been reported, suggesting possible protective roles of these compounds, due to their ability to capture metals, inhibit lipoxygenase and scavenge free radicals (19). Recently, Ferreira et al. (11) reported the antioxidative properties of two mushrooms, Lactarius deliciosus (L.) Gray and Tricholoma portentosum (Fr.) Que2 1 obtained from northeast Portugal. Moreover, the activity of the exudates from mushroom mycelia against protozoa such as the parasite that causes malaria, Plasmodium falciparum $(14,17)$ and other microorganisms (16) had been reported. Chinese Shiitake mushroom (Lentinus edodes) has also been reported to possess both anti-tumour and antimicrobial properties (15). In an earlier study, Suay et al. (25) reported that extracts of more than $75 \%$ polypores mushroom species surveyed showed antimicrobial activity and $45 \%$ of 204 mushroom species inhibited wide variety of microorganisms. Hence, mushrooms may be a source of new antimicrobial capable of inhibiting microorganisms that are resistant to common antibiotics.

*Corresponding Author. Mailing address: Department of Microbiology, Federal University of Technology, P.M.B 704. Akure, Nigeria. E-mail: ovofuta@yahoo.com 
Wasser (26) reported that the number of mushrooms on earth is estimated at 140,000 yet only $1400(10 \%)$ are known. In essence, pharmacological potentials of about $90 \%$ of mushrooms on earth are yet to be exploited. A large number of the unknown species of mushrooms whose health promoting properties are unknown reside in Africa and probably in Nigeria. This is because there are little or no data about them. Most available data on these mushrooms are on their nutritional compositions $(1,2,22)$. Most of these mushrooms are still obtained in the wild. Diverse species of mushrooms are found in Nigeria. Those that are common belongs to the following species; Termitomyces, Plerotus, Lentinus, Lenzites, Trametes, Ganoderma etc. The present study was aimed at assessing antimicrobial and free radical scavenging properties of four wild mushrooms, Termitomyces clypeatus, Termitomyces robustus, Lentinus subnudus and Lenzites species, obtained from Ado Ekiti, Nigeria.

\section{MATERIALS AND METHODS}

Fruit bodies of Termitomyces clypeatus, Termitomyces robustus, Lentinus subnidus and Lenzites species were collected during raining season between April and October 2006 in the forest along University of Ado Ekiti Road, Nigeria (N07 $41^{1}$ $06.2^{\prime \prime}$ and $\mathrm{E} 005^{\circ} 14^{1} 45.7^{\prime}$ '. The fruit bodies were morphologically identified by Dr. T.-Z, Wei of Key Laboratory of Systematic Mycology and Lichenology, Institute of Microbiology, Chinese Academy of Sciences. Molecular identification was carried out by amplifying and sequencing the Internal Transcribed Spacer (ITS 4 and ITS 5) of nuclear ribosomal DNA (nrDNA) of the mushrooms. The sequenced DNA fragments were compared with data set obtained from NCBI GenBank. The fruit bodies were dried and ground into powder prior to extraction.

\section{Preparation of macrofungi extracts}

The powder of T. clypeatus, Termitomyces robustus, Lentinus subnidus and Lenzites species were respectively extracted by soaking in ethanol in Erlenmeyer flasks shaken on orbital shaker at $180 \mathrm{rpm}$ at room temperature for 24 hour. The process of extraction was repeated as stated above for each of the mushroom samples. The extracts obtained from the extracting medium were dried to constant weight in a SUN LAB proctector laboratory hood overnight to a constant weight. The extracts were designated Termitomyces clypeatus extract (TCE), Termitomyces robustus extract (TRE), Lentinus subnidus extract (LSE) and Lenzites species extract (LZE).

\section{Chemicals}

2-deoxy-o-ribose, 1,1-diphenyl-2-picrylhydrazyl (DPPH•), Folin-Ciocalteu-reagent, Gallic acid were products of SigmaAldrich (Steinheim, Germany); 2-thiobarbituric acid (TBA) from Acros Organics (Geel, Belgium); ethylenediaminetetraacetic acid (EDTA) from Amresco (Ohio, USA); sodium acetate trihydrate, acetic acid, hydrogen peroxide $\left(\mathrm{H}_{2} \mathrm{O}_{2}\right)$, trichloroacetic acid (TCA) and ascorbic acid from Beijing Chemical Reagents Company (Beijing, China); butylated hydroxytoluene (BHT) from China National Pharmaceutical Group Shanghai Chemical Reagents Company (Shanghai, China); detection Kit of superoxide anion radical scavenging activity from Nanjing Jiancheng Bioengineering Institute (Nanjing, China). All reagents were of analytical grade.

\section{Radical scavenging activities of extracts}

Multimechanistic radical scavenging assays as listed below were employed in assessing the antioxidant property of the wild mushroom extracts (TCE, TRE, LSE and LZE).

\section{Scavenging effect of DPPH radicals}

The method of Blois (6) was used in studying the effect of extract (TCE, TRE, LSE and LZE) on DPPH • radicals with some modifications. A solution of DPPH $(0.5 \mathrm{mmol} / \mathrm{L})$ in ethanol and $0.05 \mathrm{~mol} / \mathrm{L}$ acetate buffer $(\mathrm{pH} 5.5)$ were prepared. Extracts in solution $(0.1 \mathrm{ml})$ at different concentrations was mixed with $2 \mathrm{ml}$ of acetate buffer, $1.9 \mathrm{ml}$ of absolute ethanol and $1 \mathrm{ml} \mathrm{DPPH}$ solution. The mixture was shaken immediately after adding DPPH and allowed to stand at room temperature in the dark for $30 \mathrm{~min}$. The decrease in absorbance at $517 \mathrm{~nm}$ was measured using a UNICO 2100 spectrophotometer. BHT was used as positive control and the sample solution without DPPH was used as blank. The radical scavenging activity was measured as a decrease in absorbance of DPPH and calculated as:

$$
\text { Scavenging activity }(\%)=\frac{A b-(A s-A s b)}{A b} \times 100
$$

Where $\mathrm{Ab}$, As and Asb are absorbances at $517 \mathrm{~nm}$ of DPPH of the blank, extract or control and sample blank respectively.

\section{Scavenging effect on hydroxyl radical}

The determination of scavenging effect of extracts (TCE, TRE, LSE and LZE) on hydroxyl radicals was carried out as described by Halliwell et al. (12). The reaction mixture in a final volume of $1.0 \mathrm{ml}$, containing $0.4 \mathrm{ml}$ of $20 \mathrm{mmol} / \mathrm{mL}$ sodium phosphate buffer ( $\mathrm{pH} 7.4), 0.1 \mathrm{ml}$ of $0.0625 \mathrm{mg} / \mathrm{mL}$ to $1 \mathrm{mg} / \mathrm{mL}$ extracts, $0.1 \mathrm{ml}$ of $60 \mathrm{nmol} / \mathrm{L}$ deoxyribose, $0.1 \mathrm{ml}$ of $10 \mathrm{mmol} / \mathrm{L}$ hydrogen peroxide, $0.1 \mathrm{ml}$ of $1 \mathrm{mmol} / \mathrm{L}$ ferric chloride, $0.1 \mathrm{ml}$ of $1.04 \mathrm{mmol} / \mathrm{LEDTA}$ and $0.1 \mathrm{~mL}$ of $2 \mathrm{mmol} / \mathrm{L}$ ascorbic acid was incubated at $37^{\circ} \mathrm{C}$ for $1 \mathrm{~h}$. Solutions of $\mathrm{FeCl}_{2}$ and ascorbic acid were made up immediately before use in de-ionised water. The reaction was stopped by adding $1 \mathrm{ml}$ of $17 \mathrm{mmol} / \mathrm{L}$ thiobarbituric acid (TBA) and $1 \mathrm{ml}$ of $17 \mathrm{mmol} / \mathrm{L}$ trichloroacetic acid (TCA). The mixture was boiled for $15 \mathrm{~min}$, cooled in ice and then the absorbance measured at $532 \mathrm{~nm}$ using a UNICO 2100 spectrophotometer. BHT was used as positive control while distilled water in place of extracts or BHT was used as 
blank and the sample solution without adding deoxyribose as sample blank.

$$
\text { Scavenging activity }(\%)=\frac{A b-(A s-A s b)}{A b} \times 100
$$

Where $\mathrm{Ab}$ is absorbance at $532 \mathrm{~nm}$ of the blank; As is absorbance of blank at $532 \mathrm{~nm}$ and Asb is absorbance of extract or BHT at $532 \mathrm{~nm}$.

\section{Scavenging effect on superoxide anion radicals}

A commercial kit was used for this assay. Superoxide anion radicals were generated by xanthine/xanthine oxidase system and reacted with, 4-iodiphenyl-5-phenyltertazolium chloride to form formazan, a coloured compound which was spectrophotochemically quantified at $550 \mathrm{~nm}$. The production of formazan is inversely related to the superoxide anion radical scavenging activity of tested sample. The final results were expressed as the inhibition degree of formazan production. BHT was used as positive control and distilled water in place of extracts or BHT as blank. The \% of inhibition of superoxide anion radicals was calculated using the formula below.

$$
\text { Scavenging activity }(\%)=\frac{A b-(A s-A s b)}{A b} \times 100
$$

Where $\mathrm{Ab}$ is absorbance at $550 \mathrm{~nm}$ of the blank; As is absorbance of blank at $550 \mathrm{~nm}$ and Asb is absorbance of extract or BHT at $550 \mathrm{~nm}$.

\section{Ferrous ion chelating assay}

The chelation of ferrous ion by the extracts was ascertained by the methods of Decker and Welch (8). One millilitre of extracts with concentration ranging between 0.25 to $4 \mathrm{mg} / \mathrm{mL}$ was mixed with $3.7 \mathrm{~mL}$ of deionised water and then the mixture was reacted with ferrous chloride $(2 \mathrm{mmol} / \mathrm{L}, 0.1 \mathrm{~mL})$ and ferrozine $(5 \mathrm{mmol} /$ $\mathrm{L}, 0.2 \mathrm{~mL}$ ) for $20 \mathrm{~min}$. The absorbance at $562 \mathrm{~nm}$ was determined spectrophotometrically. EDTA was used as positive control. Chelating activity on ferrous ion was calculated using the equation below:

$$
\text { Chelating effect }(\%)=\frac{A b-A s}{A b} \times 100
$$

Where $\mathrm{Ab}$ is the absorbance of the blank without extract or EDTA and As is the absorbance in the presence of extract or EDTA.

\section{Antimicrobial assay \\ Indicator organisms used for antimicrobial assay}

A total of 8 microbial strains made up of 6 bacterial strains and 2 yeast strains were used. The microbial strains were Bacillus subtilis ATCC 6633, Bacillus cereus CMCC1.1846, Alcaligenes faecalis CMCC1.1837, Staphylococcus aureus ATCC 6538, Shigella dysenteriae CMCC 51252, Salmonella typhimurium CMCC 1.1174, Candida albican ATCC10231 and Cryptococcus neoformans CMCC 1038. Microbial strains were obtained from China general microbial culture collection centre (CGMCC).

\section{Antimicrobial activity}

Antimicrobial activity of extracts was determined by the agar well diffusion method (23). Bacteria used as indicator organism were cultivated on nutrient agar medium at $36 \pm 1^{\circ} \mathrm{C}$ for 24 hour while the yeast were cultivated on Yeast malt extract agar at $26 \pm 1^{\circ} \mathrm{C}$ for 48 to 72 hour. Aliquot of culture $(100 \mu \mathrm{l})$ was evenly spread on the surface of the solidified agar. Wells of $7 \mathrm{~mm}$ were bored in the agar with sterile cork borers. The extract $(100 \mu \mathrm{l})$ dissolved in dimethylsulfoxide (DMSO) to concentration of 12.5 to $100 \mathrm{mg} / \mathrm{mL}$ and filtered through $0.22 \mu \mathrm{m}$ membrane filter was introduced into the wells. The plates were incubated at $36 \pm 1^{\circ} \mathrm{C}$ for 24 hour for bacteria while the fungi were incubated at $26 \pm 1^{\circ} \mathrm{C}$ for 48 to 72 hour. Tetracycline and ampicillin were used as standard antibacterial while nystatin was used as antifungal standard under the conditions specified for bacteria and fungi respectively. The diameter of the inhibition zones were measured in milliliters. Inhibition zones were measured in triplicates (three plates per indicator organism).

\section{Minimum inhibitory concentration}

Dilutions of extracts (TCE, TRE, LSE and LZE) ranging from $12.5 \mathrm{mg} / \mathrm{mL}$ to $100 \mathrm{mg} / \mathrm{mL}$ were prepared. The agar diffusion method described above was used to screen the antimicrobial effect of the different concentrations of extracts. Agar well in which DMSO was added served as negative control. The tests were performed in triplicates.

\section{Statistical analysis}

All experiments were carried out in triplicates. Data obtained were analyzed by one way analysis of variance and means were compared by Duncan's multiple range tests (SPSS 11.5 version). Differences were considered significant at $\mathrm{p}<0.05$.

\section{RESULTS AND DISCUSSION}

Generally, the most used genomic region for molecular characterization of fungi is the ITS region (internal transcribed spacer). It presents several characteristics making it a pertinent tool to identify and analyze phylogenic molecules of fungi at species level differentiating between a large interspecific variability and a weak intraspecific variability (4). Hence, ITS region of rDNA of the fungi was used for their identification. Table 1 shows the molecular identity of macrofungi that were earlier identified using phenotypic data. The percentage identity of macrofungi obtained from BLAST analysis varies between 
Table 1. Genomic identification based on rDNA ITS sequences of wild macrofungi collected from Ado Ekiti, Nigeria

\begin{tabular}{cccc}
\hline$*$ Code & Phenotypic identity & $\begin{array}{c}\text { Closest relative from NCBI } \\
\text { data base }\end{array}$ & $\begin{array}{c}\text { \% Identity with sequence } \\
\text { from NCBI GenBank }\end{array}$ \\
\hline LS & Lentinus subnidus & Lentinus tigrinus & 80 \\
TC & Termitomyces clypeatus & T. striatus & 85 \\
TR & Termitomyces robustus & T. eurhizus & 96 \\
LZ & Lenzites species & Lenzites betulina & 97 \\
\hline
\end{tabular}

* LS: Lentinus subnidus; TC: Termitomyces clypeatus; TR: Termitomyces robustus; LZ: Lenzites species.

$80 \%$ and $97 \%$. It has been reported that percentage similarity of $70 \%$ and above shows that strains identified are closely related (10).

Appreciable yield of 21.73 to $44.60 \mathrm{mg} / \mathrm{g}$ was obtained as ethanolic extracts from TRE, TCE, LSE and LZE (Table 2). Ethanolic extracts of TRE and TCE were higher and significantly different $(\mathrm{P}<0.05)$ from what were obtained in LSE and TZE.

Scavenging effect of extracts on DPPH radicals was concentration dependent (Fig. 1). LSE exhibited a significantly different $(\mathrm{P}<0.05)$ DPPH scavenging effect at $2 \mathrm{mg} / \mathrm{mL}$ than other extracts. However, BHT (positive control) has a significantly different $(\mathrm{P}<0.05)$ DPPH scavenging effect at all concentrations than the extracts. Scavenging effect of BHT at all concentrations was not concentration dependent. In a previous report, the highest scavenging activities on DPPH radical obtained for edible mushroom such as Lentinus edodes (Berk.) Singer was 55.4\% and Volvariella volvacea (Bull.) Singer $37.9 \%$, at the concentrations of $1-9 \mathrm{mg} / \mathrm{mL}$ (7). The results of DPPH scavenging effect of LSE and LZE were higher than what was reported by Cheung et al. (7). DPPH assay is a widely used method to evaluate antioxidant activities in a relatively short time compared to other methods (21). It has the advantage of being unaffected by certain side reactions which is common in laboratory-generated free radicals such as the hydroxyl and superoxide anion (3).

In ferrous ion reduction, the general ability of the extracts to donate electrons is tested (13). Extracts exhibited a concentration dependent scavenging effect on ferrous ion (Fig. 2). However,

Table 2. Total ethanolic yield ( $\mathrm{mg} / \mathrm{g})$ from wild mushrooms

\begin{tabular}{cl}
\hline Mushrooms & Total yield* $^{*}$ \\
\hline TRE & $44.60^{\mathrm{b}} \pm 1.65$ \\
TCE & $40.03^{\mathrm{b}} \pm 3.07$ \\
LSE & $26.60^{\mathrm{a}} \pm 1.43$ \\
LZE & $21.73^{\mathrm{a}} \pm 1.43$ \\
\hline
\end{tabular}

Values are mean \pm standard deviation of three replicates. *Values along column with different superscript are significantly different $(\mathrm{P}<0.05)$. scavenging effect of EDTA (control) on ferrous ion was not concentration dependent. The ferrous ion scavenging effect of LSE at $4 \mathrm{mg} / \mathrm{mL}$ concentration was $96.55 \%$. This was higher and significantly different $(\mathrm{P}<0.05)$ from ferrous ion chelating effects exhibited by the other extracts. TRE exhibited the lowest ferrous ion chelating effect of $23.08 \%$ at $4 \mathrm{mg} / \mathrm{mL}$ concentration. In a previous study, Mau et al. (17) reported the ability of methanolic extracts from commercial medicinal mushrooms including $G$ lucidiun, G. lucidium antler and G. tsugae to reduce ferrous ion.

Hydroxyl ion scavenging effect of extracts was not concentration dependent (Fig. 3). There was no significant

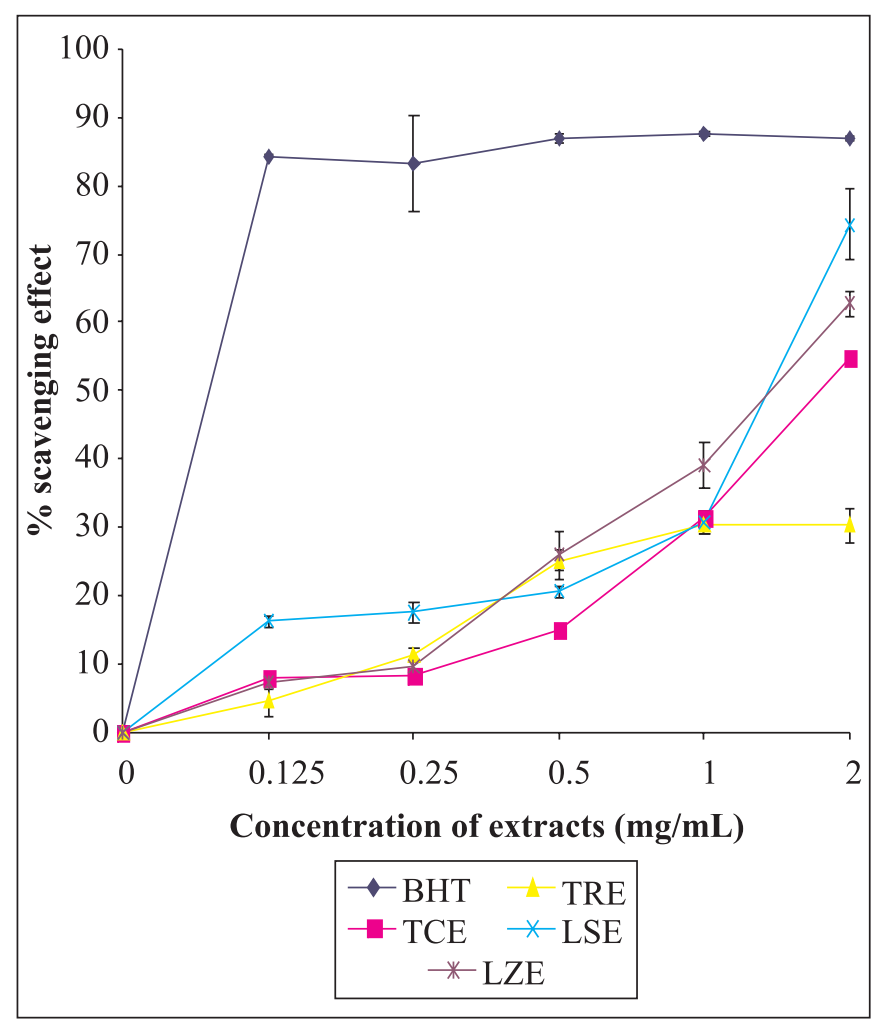

Figure 1. Scavenging activity of extracts on DPPH radicals. Each value is mean \pm standard deviation $(n=3)$. 


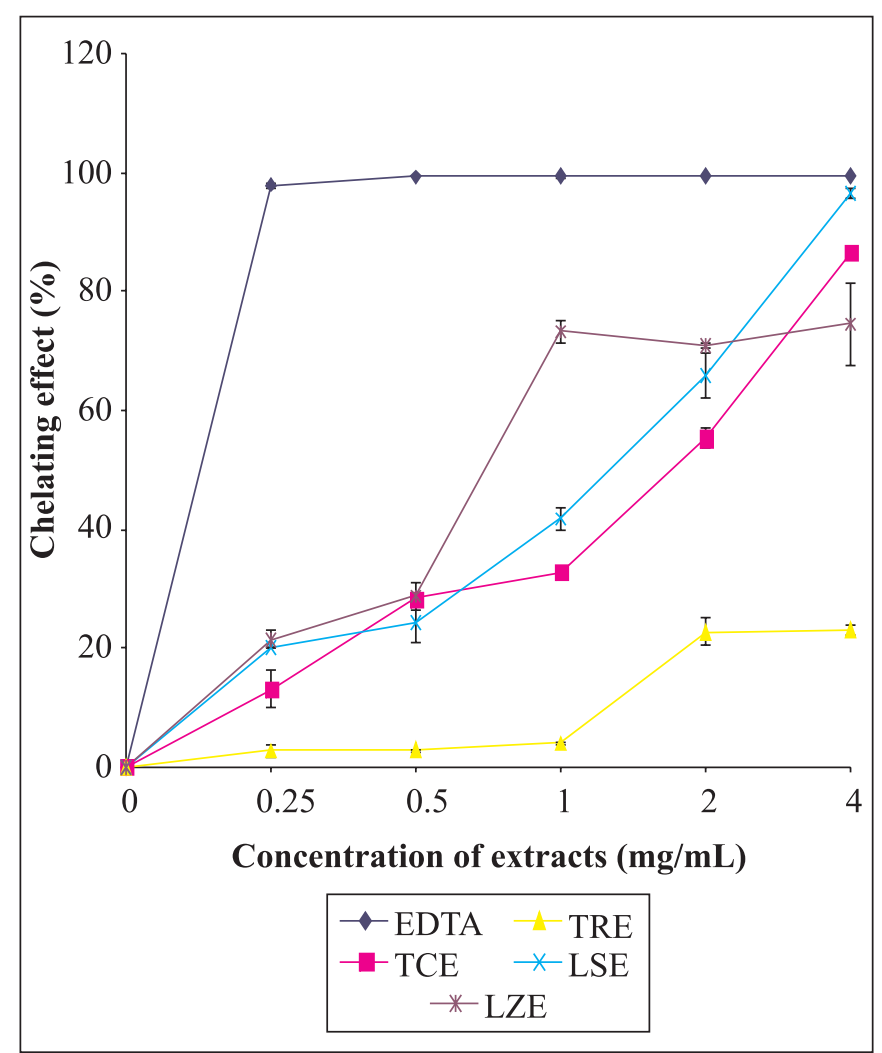

Figure 2. Ferrous ion chelating effect of extracts. Each value is mean \pm standard deviation $(n=3)$.

difference in the hydroxyl ion scavenging effect of extracts and BHT at concentrations of 0.0625 and $1 \mathrm{mg} / \mathrm{ml}$. TCE and LPE, however, exhibited a higher and significantly different hydroxyl ion scavenging effect at $0.5 \mathrm{mg} / \mathrm{mL}$ concentration. The highly reactive hydroxyl radical can cause oxidative damage to DNA, lipids and proteins (24). A very high hydroxyl ion scavenging ability exhibited suggests that extracts have potentials of being used as alternative to synthetic antioxidants in arresting oxidative activity of hydroxyl ion.

Superoxide anion scavenging activity of extracts and BHT were concentration dependent (Fig. 4). TRE and TCE exhibited a significant superoxide anion scavenging effect of $72.95 \%$ and $98.80 \%$ respectively at $2.0 \mathrm{mg} / \mathrm{mL}$ concentration. Superoxide is biologically important since it can be decomposed to form stronger oxidative species such as singlet oxygen and hydroxyl radicals hence, they are very harmful to cellular components of biological systems (27).

Table 3 shows the results of antimicrobial effect of extracts on selected microorganisms. Extracts showed good antimicrobial activity against the two yeasts, $C$. albicans and C. neoformans. There were no observable differences in the susceptibility of Gram positive and Gram negatve bacteria to

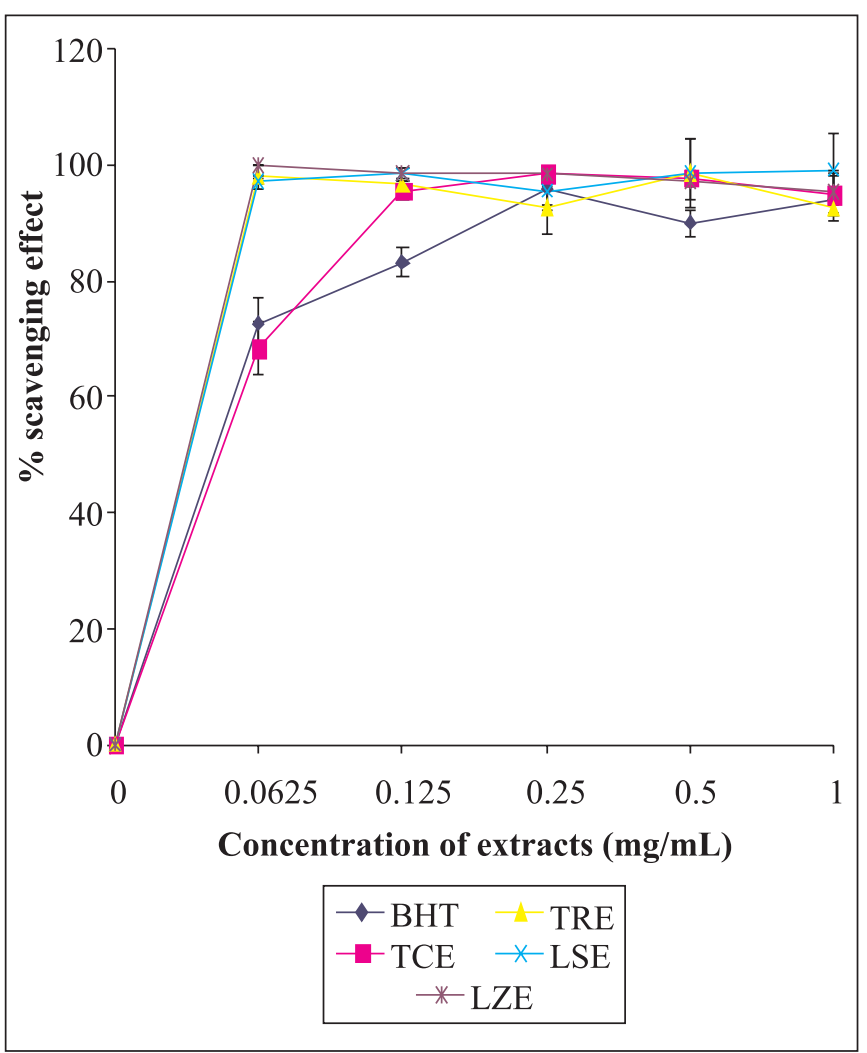

Figure 3. Scavenging effect of extracts on hydroxyl radicals. Each value is mean \pm standard deviation $(n=3)$.

the antimicrobial effect of extracts. Only Alcaligenes faecalis, a Gram positive bacteria, that exhibited more susceptibility to the antimicrobial effect of extracts. The MIC of extracts ranged between $12.5 \mathrm{mg} / \mathrm{mL}$ to $100 \mathrm{mg} / \mathrm{mL}$ (Table 4). C. albicans, $C$. neoformans and Alcaligenes faecalis were more susceptible to the antimicrobial effect of LSE and LZE at the lowest concentration of $12.5 \mathrm{mg} / \mathrm{mL}$. Mushrooms need antibacterial and antifungal compounds to survive in their natural environment (16). Hence, they may be rich sources of natural antibiotics. Suay et al. (24) had earlier reported that extracts of more than $75 \%$ polypores mushroom species surveyed showed antimicrobial activity and $45 \%$ of 204 mushroom species inhibited wide variety of microorganisms. In essence, unexploited mushrooms such as the ones found in Nigeria may be sources of new antimicrobials that can tackle the problem of drug resistance that is rampart in the country at present.

Results obtained from this study revealed that LSE and LZE displayed better activity in scavenging for DPPH and ferrous ion radicals while TRE and TCE exhibited better superoxide anion scavenging activity. Scavenging activity of all extracts on hydroxyl radical was not significantly different from what was observed for BHT. The extracts were also able to inhibit the 
Table 3. Inhibition zone $(\mathrm{mm})$ of crude extracts $50 \mathrm{mg} / \mathrm{ml}$ from wild mushrooms against indicator organisms.

\begin{tabular}{lcccccc}
\hline \multicolumn{1}{c}{ Indicator organisms } & LZE & LSE & TCE & TRE & Tetracycline $(30 \mu \mathrm{g} / \mathrm{ml})$ & Nystatin $(40 \mu \mathrm{g} / \mathrm{ml})$ \\
\hline Candida albicans & 15 & 15 & 11.5 & 10 & NT & $10.3 \pm 0.5$ \\
Cryptococcus neoformans & 22 & 17.5 & 13 & 13 & NT & $9.3 \pm 1.2$ \\
Bacillus cereus & - & 11 & - & 9 & $25.6 \pm 1.2$ & NT \\
Bacillus subtilis & 11 & 9 & - & - & $35.0 \pm 1.5$ & NT \\
Staphylococcus aureus & - & 8 & - & - & $5.0 \pm 1.0$ & NT \\
Shigella dysenteriae & - & - & - & - & $4.0 \pm 0.0$ & NT \\
Salmonella typhimurium & 10 & - & - & - & $4.0 \pm 0.0$ & NT \\
Alcaligenes faecolis & 14.5 & 15 & 13 & 13 & $23.7 \pm 3.7$ & NT \\
\hline
\end{tabular}

Values are means of three replicates. NT: Not tested; -: No inhibition.

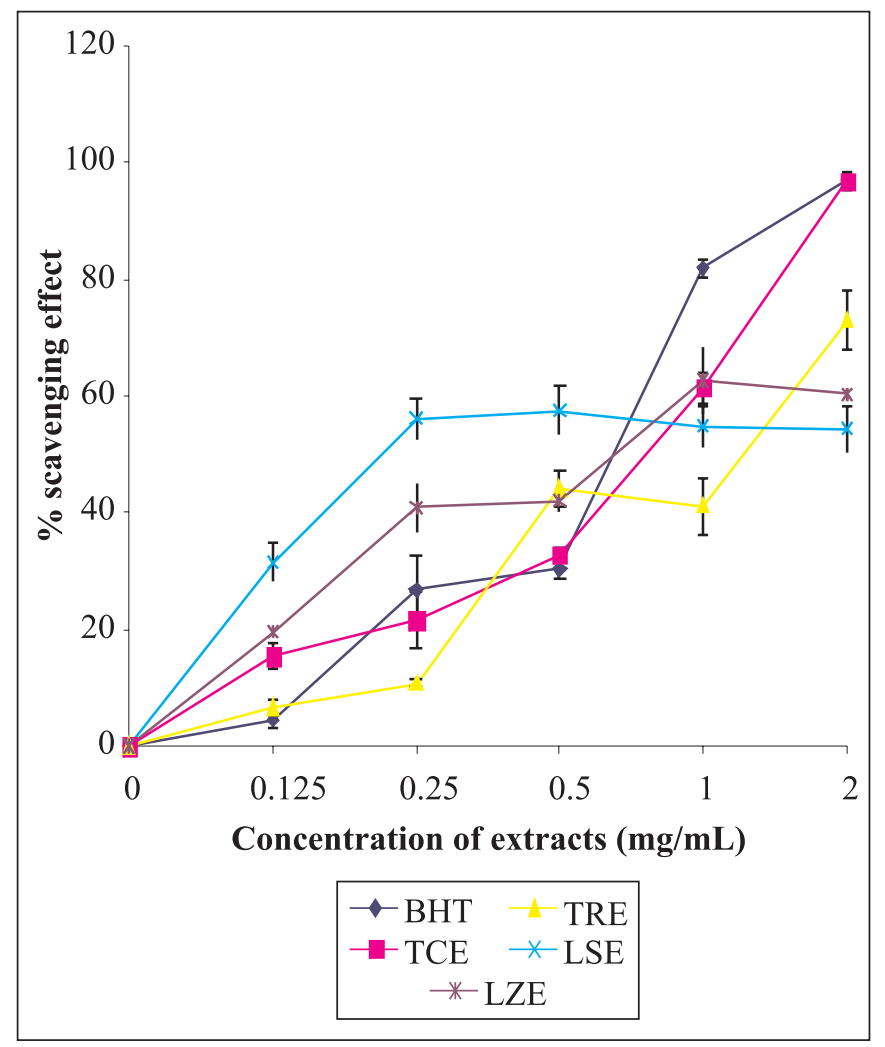

Figure 4. Scavenging effect of extracts on superoxide anion. Each value is mean \pm standard deviation $(n=3)$.

growth of all the indicator organisms at concentrations between $12.5 \mathrm{mg} / \mathrm{mL}$ to $100 \mathrm{mg} / \mathrm{mL}$. LSE and LZE, however, displayed a better antimicrobial activity against the indicator organisms. Hence, extracts (LSE, TCE, TRE and LZE) have potential of being used as source of biopharmaceutical substances with antioxidant and antimicrobial properties. Further work aimed at isolation and identification of specific antioxidant and antimicrobial agents in extracts is the next focus of this research.
Table 4. Minimum inhibitory concentration (MIC) of extracts $(\mathrm{mg} / \mathrm{ml})$ from wild mushrooms against indicator organisms.

\begin{tabular}{lcccc}
\hline \multicolumn{1}{c}{ Indicator Organisms } & LZE & LSE & TCE & TRE \\
\hline Candida albicans & 12.5 & 12.5 & 50 & 12.5 \\
Cryptococcus neoformans & 12.5 & 12.5 & 50 & 50 \\
Bacillus cereus & 100 & 50 & 100 & 50 \\
Bacillus subtilis & 50 & 50 & 100 & 100 \\
Staphylococcus aureus & 100 & 50 & 100 & 100 \\
Shigella dysenteriae & 100 & 50 & 100 & 50 \\
Salmonella typhimurium & 50 & 100 & 100 & 100 \\
Alcaligenes faecalis & 12.5 & 12.5 & 50 & 50 \\
\hline
\end{tabular}

Values are means of three replicates.

\section{ACKNOWLEDGEMENTS}

The Author wishes to acknowledge the financial support of CAS-TWAS. OVO is a recipient of the CAS-TWAS Postdoctoral fellowship to China. Prof. Y.-J, Yao is also gratefully acknowledged for hosting OVO in his laboratory (Key Laboratory of Systematic Mycology and Lichenology, Institute of Microbiology, Chinese Academy of Sciences, Beijing 100101, Peoples' Replublic of China).

\section{RESUMO}

\section{Atividade sequestradora de radicais livres e propriedades antimicrobianas de extratos de cogumelos selvagens}

Foram investigadas as propriedades antioxidantes e antimicrobianas de extratos obtidos de quatro cogumelos selvagens da Nigéria: Termitomyces clypeatus (TCE), Termitomyces robustus (TRE), Lentinus subnudus (LSE) and Lenzites species (LZE). LSE e LZE, na concentração de $2 \mathrm{mg} / \mathrm{ml}$, 
apresentaram boa atividade sequestrante contra 2,2'-difenil- $\beta$ picrilhidrazil (DPPH') e radicais ferrosos. Entretanto, TER e TCE a $2 \mathrm{mg} / \mathrm{ml}$ apresentaram melhor efeito sequestrador de anions superóxido .Todos os extratos apresentaram feito semelhante de seqüestro de radicais hidroxila como BHT usado como controle. Além disso, todos os extratos dos cogumelos selvagens, na concentração de $12,5 \mathrm{mg} / \mathrm{ml}$ até $100 \mathrm{mg} / \mathrm{ml}$, foram capazes de inibir a multiplicação de todos os microrganismos indicadores testados, mas LSE e LZE apresentaram efeito antimicrobiano mais intenso. Os resultados sugerem que os extratos obtidos dos quatro cogumelos selvagens podem ser fontes de novos compostos bioativos com atividade antimicrobiana e antioxidante.

Palavras-chave: Atividade sequestradora de radicais livres, atividade antimicrobiana, cogumelos selvagens

\section{REFERENCES}

1. Aletor, V.A. (1993). Allelochemicals in plant foods and feedingstuffs: 1. Nutritional, Biochemical and physiopathological aspects in animal production. Vet. Human Toxicol., 35 (1): 57-67

2. Alofe, F.V.; Odeyemi, A.O.; Oke, O.L. (1996). Three wild mushrooms from Nigeria: their proximate and mineral composition Plant food for Human Nutrition, 49: 63-67.

3. Amarowicz, P.; Pegg, R.B.; Rahimi-Moghaddam, P.; Barl, B.; Weil, J.A. (2004). Free-radical scavenging capacity and antioxidant activity of selected plant species from the Canadian prairies. Food Chem., 84: 551-562.

4. Anderson, J.B.; Stasovski, E. (1992). Molecular phylogeny of Northern Hemisphere species of Armillaria. Mycologia, 84: 505-516.

5. Barros, L.; Calhelha, R.C.; Vaz, J.A.; Ferreira, I.C.F.R.; Baptista, P.; Estevinho, L.M. (2007). Antimicrobial activity and bioactive compounds of Portuguese wild edible mushrooms methanolic extracts. Euro. Food Res. Technol., 225:151-156.

6. Blois, M.S. (1958). Antioxidants determination by the use of a stable free radical. Nature, 181: 1199-1120.

7. Cheung, L.M..; Cheung, P.C.K.; Oei, V.E.C. (2003). Antioxidant activity and total phenolics of edible mushroom extracts. Food Chem., 81: 249-255

8. Decker, E.A.; Welch, B. (1990). Role of ferritin as a lipid oxidation catalyst in muscle food. J. Agri. Food Chem., 38: 674-677.

9. Demain, A.L. (1999). Pharmaceutically active secondary metabolites of microorganisms. Appl. Microbiol. Biotechnol., 52(4): 455-63.

10. Desmasures, N.; Mangin, L.; Corroler, D.; Gueguen, M. (1998). Characterisation of lactococci isolated from milk produced in the Camembert region of Normandy. J. Appl. Microbiol., 85: 999-1005.

11. Ferreira, I.C.F.R.; Baptista, P.; Vilas-Boas, M.; Barros, L. (2007). Free-radical scavenging capacity and reducing power of wild edible mushrooms from northeast Portugal: individual cap and stipe activity. Food Chem., 100: 1511-1516.

12. Halliwell, B.; Gutteridge, J.M.C.; Aruoma, O.I. (1987). The deoxyribose method: A simple 'Test-Tube' assay for determination of rate constants for reactions of hydroxyl radicals. Analytical Biochem., 165: 215-219.

13. Hinnerburg, I.; Damien- Dorman, H.J.; Hiltunen, R. (2006). Antioxidant activities of extracts from selected culinary herbs and spices. Food Chem., 97: 122-129.

14. Isaka, M.; Tantichareon, M.; Kongsaeree, P.; Thebtaranonth, Y. (2001). Structures of Cordypyridones A-D, Antimalarial N-Hydroxyand N-Methoxy-2-pyridones from the Insect Pathogenic Fungus Cordyceps nipponica. J. Organic Chem., 66: 4803-4808.

15. Jong, S.C.; Birmingham, J.M. (1993). Medicinal and therapeutic value of the Shiitake mushroom. Advan. Appl. Microbiol., 39: 153-184.

16. Lindequist, U.; Niedermeyer, T.H.J.; Julich, W-D. (2005). The pharmacological potential of mushrooms-Review. E CAM, 2 (3): 285-299.

17. Lovy, A.; Knowles, B.; Labbe, R.; Nolan, L. (1999). Activity of Edible Mushrooms Against the Growth of Human T4 Leukemic Cancer Cells, HeLa Cervical Cancer Cells, and Plasmodium falciparum. J. Herbs, Spices Medicinal Plants, 6: 49-57.

18. Mau, J.L.; Chang, C.N.; Chen, C.C. (2002). Antioxidant properties of several medicinal mushrooms. J. Agric Food Chem., 50: 60726077.

19. Mau, J.L.; Chang, C.N.; Huang, S.J.; Chen, C.C. (2004). Antioxidant properties of methanolic extracts from Grifola frondosa, Morchella esculenta and Termitomyces albuminosus mycelia. Food Chem., 87: 111-118.

20. Mizuno, T. (1999). The extraction and development of antitumor active polysaccharides from medicinal mushrooms in Japan- Review. Inter. J. Medicinal mushrooms, 1, pp. 9-30.

21. Mokbel, M.S.; Hashinaga, F. (2006). Evaluation of the antioxidant activity of extracts from buntan (Citrus grandis Osbeck) fruit tissues. Food Chem., 94: 529-534.

22. Ola, F.L.; Oboh, G. (2001). Nutrient distribution and zinc bioavailability. Estimation in some tropical edible mushrooms. Nahrung, 45: 67-68.

23. Schinor, E.C.; Salvador, M.J.; Ito, I.Z.; Dias, D.A. (2007). Evaluation of the antimicrobial activity of crude extracts and isolated constituents from Chresta scapigera. Braz. J. Microbiol., 38: 145-149.

24. Spencer, J.P.E.; Jenner, A.; Aruoma, O.I.; Evans, P.J.; Kaur, H.; Dexter, D.T. (1994). Intense oxidative DNA damage promoted by L-DOPA and its metabolites, implications for neurodegenerative disease. FEBS Lett., 353: 246-250.

25. Suay, I.; Arenal, F.; Asenio, F.; Basilio, A.; Cabello, M.; Diez, M.T. (2000). Screening of basidiomycetes for antimicrobial activities. Antonie van Leeuwenhoek, 78: 129-139.

26. Wasser, S.P. (2002). Medicinal mushrooms as a source of antitumour and immunostimulating polysaccharides. Appl. Microbiol. Biotechnol., 60: 258-274.

27. Zhao, G.R.; Xiang, Z.J.; Ye, T.X.; Yuan, Y.J.; Guo, Z.X. (2006). Antioxidant activities of Salvia miltiorrhiza and Panax notoginseng. Food Chem., 99: 767-774. 